\title{
Engineering Microbial Biofilms for Improved Productivity of Biochemicals Important in Restoration of Degraded Ecosystems
}

\author{
Mahesh Premarathna1, Thilini Rathnathilaka1, Gamini Seneviratne ${ }^{1 *}$, Sumedha Madawala ${ }^{2}$ \\ ${ }^{1}$ Microbial Biotechnology Unit, National Institute of Fundamental Studies, Kandy, Sri Lanka \\ ${ }^{2}$ Deparment of Botany, Faculty of Science, University of Peradeniya, Peradeniya, Sri Lanka \\ Email: *gamini.se@nifs.ac.lk
}

How to cite this paper: Premarathna, M., Rathnathilaka, T., Seneviratne, G. and Madawala, S. (2022) Engineering Microbial Biofilms for Improved Productivity of Biochemicals Important in Restoration of Degraded Ecosystems. Advances in Bioscience and Biotechnology, 13, 145-158.

https://doi.org/10.4236/abb.2022.133007

Received: February 2, 2022

Accepted: March 5, 2022

Published: March 8, 2022

Copyright $\odot 2022$ by author(s) and Scientific Research Publishing Inc. This work is licensed under the Creative Commons Attribution International License (CC BY 4.0).

http://creativecommons.org/licenses/by/4.0/

(c) (i) Open Access

\begin{abstract}
Biofilms are being engineered in-vitro to produce numerous commodities like biofertilizers, pharmaceuticals, biofuels and electricity, the efficacies of which rely on the biochemicals secreted by the biofilms i.e. extracellular polymeric substances (EPS). It has been shown that once EPS-biochemicals of developed biofilms are applied to an ecosystem, they can restore degraded complex ecosystem networks for improved ecosystem functioning and sustainability. Identification of the EPS biochemicals and understanding their contributions to the network interactions in particular, are at initial stage. In the present study, using Aspergillus niger, Nostoc sp., and gram (-) Stenotrophomonas maltophilia \& gram (+) Bacillus subtilis as test fungal (F), cyanobacterial (C), and bacterial (B) counterparts, respectively we analyzed morphology and biochemical parameters of fungal-bacterial (FBBs), fungal-cyanobacterial (FCBs), cyanobacterial-bacterial (CBBs), and fungal-cyanobacterial-bacterial biofilms (FCBBs). Results revealed that the FCBBs produced the highest concentrations of lipids, proteins, and polysaccharides whereas FBBs generated the highest diversity of biochemicals. Bacterial type (i.e. gram + or - ) and microbial composition in the biofilm affected the biochemical production. Ecologically and industrially important diverse biochemicals which are used individually as medicines, bioremediating agents and industrial chemicals in human society with certain adverse and beneficial effects were detected in the biofilm-EPS. However, in the nature, simultaneous action of those diverse biochemicals applied as biofertilizers has already shown a huge potential to restore the entire agroecosystems degraded due to farmers' detrimental practices. This striking difference in utilization of the biochemicals and their enhanced effect when they act simultaneously needs further investigations for their better applications.
\end{abstract}




\section{Keywords}

Biochemicals, Biofilms, Ecosystem Restoration, Extracellular Polymeric Substances

\section{Introduction}

Microbes live mainly in two modes of lifestyles viz. planktonic (freely swimming) and surface-attached biofilm, enabling their endurance in a range of environments including extreme settings. Metabolic changes have been recognized between these two phenotypes [1]. Comparative transcriptome investigations of biofilms versus planktonic cells have confirmed that biofilm cells illustrate divergent metabolic activity with significant up-regulation of genes responsible for survival, persistence and growth in a biofilm environment [2]. This leads the biofilms to produce and secrete a wider range of biochemicals required for ecologically important processes than planktonic cells. Those biochemicals can be found in the EPS which are secreted by the biofilm itself. The EPS is now considered as the "dark matter of biofilm", because their composition has not been fully recognized yet. And also molecular interactions of the biochemicals are still to be defined [3] [4]. Here, we hypothesize that the identification and understanding of specific EPS biochemicals and their contribution to the complex interactive ecosystem networks are important to improve the productivity of the newly developed biofilms and their utilization for various biotechnologies. The knowledge gained would also be beneficial for further improvement of innovative concepts like biofilm biofertilizers [5], which are being practiced successfully in agriculture now [6], and also newly proposed notion of biofilm medicines [7], both of which are engaged in restoration of degraded agroecosystems and human body ecosystem, respectively.

The EPS biochemicals primarily consist of lipids, proteins, and polysaccharides [8]. The productivity of biofilms mainly depends on the metabolic cooperation of their resident microbes. For example, the effective microorganism (EM) technology [9] developed in Japan has shown that the mutually compatible co-existing microorganisms have excellent metabolic cooperation leading to self-sufficiency which helps its stability and a wide range of activities in the environment [10].

In 2003, in-vitro engineering of eco-friendly beneficial microbial biofilms, specifically fungal-bacterial biofilms was first introduced for biotechnological applications [10]. Later, the same concept has been reintroduced using a different terminology, i.e. synthetic microbial consortia [11]. By now, scientists have developed biofilms to produce numerous commodities like medicines, agrochemicals, bioremediating agents and industrial chemicals because of their inherent characteristics of self-immobilization, high resistance to reactants, and long-term activity, all of which facilitate continuous processing [5] [12]. Howev- 
er, optimizing biofilms to achieve desired products is a compulsion to maintain their productivity on an industrial scale.

Therefore, this study was designed to characterize the biofilm-EPS during the growth and maturation of different biofilm complexes in order to develop more productive biofilms, which would be beneficial to innovations in this field of research.

\section{Materials and Methods}

\subsection{Biofilm Formation}

To develop monoculture and mixed culture biofilms, A. niger, Nostoc sp., and $S$. maltophilial $B$. subtilis were used to represent fungi, cyanobacteria, and bacteria, respectively. From each, one loopful of microbes was introduced to $250 \mathrm{~mL}$ CCM [13] broth to produce monocultures. Appropriate volumes of each monoculture was taken and inoculated to have two contrasting ratios [F:B:C 1:3:12 $(\alpha)$, and 12:4:1 $(\beta)$ ] in to $15 \mathrm{ml}$ sterilized centrifuge tubes containing $10 \mathrm{ml}$ of CCM medium to develop different biofilms; FBBs, FCBs, BCBs and FCBBs. In this manner, 14 different biofilms were developed; $\operatorname{FBS} \alpha, \operatorname{FBB} \alpha, \operatorname{CBS} \alpha, \operatorname{CBB} \alpha, \operatorname{FCBS} \alpha$, $\mathrm{FCBB} \alpha, \mathrm{FBS} \beta, \mathrm{FBB} \beta, \mathrm{CBS} \beta, \mathrm{CBB} \beta, \mathrm{FCBS} \beta, \mathrm{FCBB} \beta, \mathrm{FC} \alpha$ and $\mathrm{FC} \beta[\mathrm{C}=$ Nostoc sp., $\mathrm{F}=A$. niger, $\mathrm{BS}=$ gram $(-)$ S. maltophilia, $\mathrm{BB}=\operatorname{gram}(+)$ B. subtilis $]$. The cultures were incubated for seven days to form biofilms. Completely randomized design was employed with three replicates for each biofilm type.

The developed biofilms were observed under low and high power of the light microscope by staining with lacto-phenol cotton blue to characterize morphological differences among the different types of biofilms.

\subsection{Extraction of the EPS}

The extraction of EPS was performed by combining physical and chemical methods [14]. A NaCl solution was prepared by dissolving $5 \mathrm{~g}$ of NaCl in $100 \mathrm{~mL}$ of sterilized distilled water. Ten microliters of the solution was added to $15 \mathrm{ml}$ centrifuge tubes that contained the developed biofilms. Then, they were subjected to ultra-sonication for 10 minutes, followed by centrifugation at $5000 \mathrm{rpm}$ for 10 minutes. Finally, the supernatant in the centrifuge tube was taken for further analyses.

\subsection{Characterization and Identification of Biochemicals in the Biofilm-EPS}

\subsubsection{Attenuated Total Reflection-Fourier Transform Infrared} (ATR-FTIR) Spectroscopy

The ATR-FTIR was carried out on a Nicolet is 50 FTIR system (Thermo Fisher Scientific) in the range of $600-4000 \mathrm{~cm}^{-1}$.

The production of different classes of biological macromolecules was quantified based on the diagnostic bands for carbohydrates $\left(960-1130 \mathrm{~cm}^{-1}\right)$, proteins $\left(1580-1700 \mathrm{~cm}^{-1}\right)$ and lipids $\left(1710-1765 \mathrm{~cm}^{-1}\right)$ [15]. 


\subsubsection{Liquid Chromatography-Mass Spectrometry (LC-MS) of EPS}

Each sample was separately diluted with HPLC grade $\mathrm{MeOH}$ to get a 1:1 solution. Then, the samples were filtered through $25 \mathrm{~mm}$ nylon mesh and then 0.45 $\mu \mathrm{m}$ filters prior toinjection. The samples were subjected to LC-MS analysis using Thermo scientific DIONEX UltiMate 3000 UHPLC system having a reversedphase Supelco C-18 analytical column $(15 \mathrm{~cm}, 4.6 \mathrm{~mm}, 3 \mu \mathrm{m})$. UHPLC system included a high-pressure pump, an automatic sample injector, a column thermostat, and a photodiode array detector. The column temperature was $28^{\circ} \mathrm{C}$. The mobile phase consisted of 100\% HPLC grade $\mathrm{MeOH}(\mathrm{A})$ and $0.001 \%(\mathrm{v} / \mathrm{v}$ ) analytical grade formic acid in ultrapure water (B). The separation was carried out in gradient elution as follows: until $2 \mathrm{~min} 90 \%$ of B, at $28 \mathrm{~min} 2 \%$ of B, at 30 $\min 2 \%$ of $\mathrm{B}$, at $32 \min 90 \%$ of $\mathrm{B}$, and $90 \%$ of B until 35 min with a flow rate of $0.4 \mathrm{~mL} / \mathrm{min}$. The injection volume was $10 \mu \mathrm{L}$. Spectral data from all peaks were accumulated in the range $200-400 \mathrm{~nm}$ and UV-visible chromatograms were recorded at 224, 254, 280, and $360 \mathrm{~nm}$ with $1 \mathrm{~mm}$ bandwidth. The data collection rate was $5 \mathrm{~Hz}$. Response time was $2.000 \mathrm{~s}$.

Thermo Scientific LCQ Fleet mass spectrometer, operated with an electrospray (ESI) ion source was coupled to the UHPLC system. Nitrogen generated from pressurized air by F-DGSi Alliance V350 laboratory gas generator was used as a nebulizer gas and drying gas. The drying gas was heated to $350^{\circ} \mathrm{C}$ and introduced to the capillary region at a flow rate of 36 arbitrary units. The capillary was heated to $320^{\circ} \mathrm{C}$ and the capillary potential was set at $-40 \mathrm{~V}$. Spray voltage was $4500 \mathrm{~V}$ and the corona current was $25 \mathrm{~mA}$. Full data acquisition was performed for mass spectroscopy, scanning from $\mathrm{m} / \mathrm{z}$ range 100 - 1500 in centroid mode in negative polarity. The activation type was collision-induced dissociation. The normalized collision energy was 35 with an activation time of 30.00 ms.

\subsubsection{Identification of Biochemicals in the Biofilm-EPS}

The biochemicals in the biofilm-EPS were identified by analyzing LC-MS chromatograms using NIST Mass Spectral Library (National Institute of Standards and Technology, Gaithersburg, MD, USA). The molecules which were identified with $100 \%$ and $90 \%-100 \%$ probabilities were considered as compounds with confirmed and predicted structures, respectively.

\subsection{Statistical Analysis}

The data were analyzed using the statistical software Minitab version 17. FTIR absorbance data were analyzed using one-way analysis of variance (ANOVA), followed by Tukey's HSD test. Probability $\leq 0.05$ was used as the threshold for significance.

\section{Results and Discussion}

\subsection{Morphology of Biofilms}

In the FBB, fungal filaments acted as the biotic surface for bacterial cells to co- 
lonize (Figure 1), as was also observed in previous studies [16] [17]. The attachment of bacterial cells to fungal filaments initiated within the first 48 hours of the biofilm formation and reached to its maximum attachment by 96 hours. The accumulation of EPS was clearly observed during the maturation of the FBB, and the highest quantity of EPS was observed on day 7 (Figure 1).

The same observations were made in CBBs. In the FCBs, fungal filaments were intertwined with cyanobacterial threads and they were surrounded by EPS. In the FCBBs, bacterial cells attached to fungal and cyanobacterial filaments surround by an extracellular matrix.

\subsection{Characterization of the Biofilm-EPS}

Production of mainly lipids, polysaccharides and proteins was observed in the biofilm-EPS (Figure 2). The highest amounts of lipids, proteins and polysaccharides were produced by the FCBS $\alpha$ biofilm, whereas the lowest amounts were produced by the $\mathrm{CBB} \alpha, \mathrm{CBS} \beta$ and $\mathrm{FC} \alpha$, respectively (Figure 2).

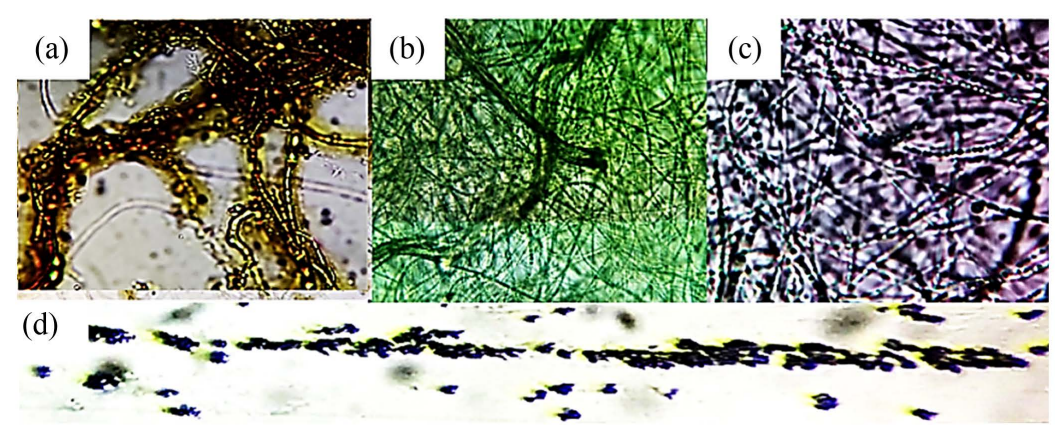

Figure 1. Morphological characteristics of (a) Fungal-bacterial, (b) Cyanobacterial-fungal, (c) Cyanobacterial-bacterial-fungal, and (d) Cyanobacterial-bacterial biofilms. Magnification $400 \times$.

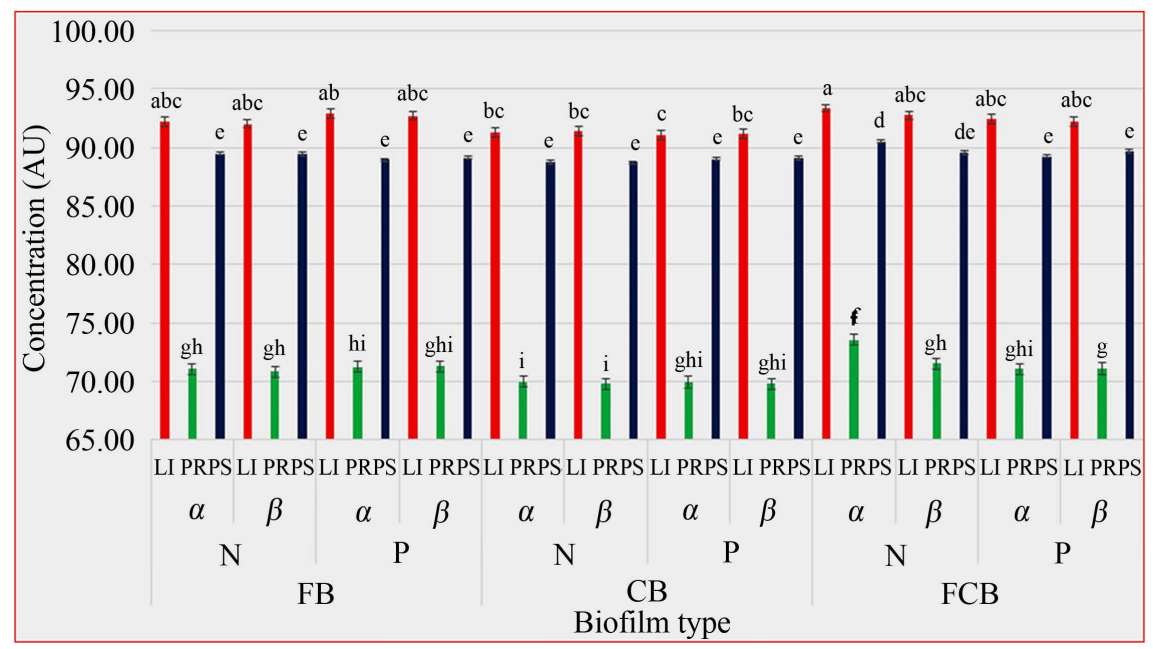

Figure 2. EPS biochemicals produced by different biofilms $(\mathrm{C}=$ Nostoc sp., $\mathrm{F}=$ Aspergillus niger, $\mathrm{N}=$ gram negative Stenotrophomonas maltophilia, $\mathrm{P}=$ gram positive Bacillus subtilis, $\alpha=$ inoculation ratio of $\mathrm{F}: \mathrm{C}: \mathrm{B}=1: 12: 3, \beta=$ inoculation ratio of $\mathrm{F}: \mathrm{C}: \mathrm{B}=12: 1: 4$, $\mathrm{LI}=$ lipids, $\mathrm{PR}=$ proteins, $\mathrm{PS}=$ polysaccharides $)$. 
In FCBBs, $S$. maltophilia performed better than B. subtilis in producing lipids, proteins and carbohydrates (Figure 2). In FBBs, B. subtilis did better than $S$. maltophilia in producing lipids (Figure 2), and S. maltophilia and B. subtilis performed similarly in producing proteins (Figure 2). Moreover, S. maltophilia produced higher amounts of carbohydrates than B. subtilis (Figure 2). In CBBs, S. maltophilia and B. subtilis performed similarly in producing lipids and proteins (Figure 2), but B. subtilis produced a higher amount of polysaccharides than S. maltophilia (Figure 2).

In FCBBs, the ratio $\alpha$ performed better than the ratio $\beta$ in producing lipids, proteins and carbohydrates (Figure 2). In FCBs, the ratio $\beta$ produced a higher amount of carbohydrates than the ratio of $\alpha$ (Figure 2). In FBBs and CBBs, both ratios performed similarly in producing lipids, proteins and carbohydrates (Figure 2).

Compound diversity of the fungal-bacterial biofilms (here the A. niger-S. maltophilia biofilm) was higher than that of the other biofilms (Figure 3). Possibly, it is the reason for the success of fungal-bacterial biofilms in industry [18]. Therefore, the $A$. niger-S. maltophilia biofilm was characterized further in order to identify the composition of its biofilm-EPS.

\subsection{Characterization of $A$. niger-S, maltophilia Biofilm-EPS}

Production of mainly lipids, polysaccharides and proteins was observed in the biofilm-EPS (Figure 4). They are reported to play a crucial role in gene regulatory, protein and signaling networks which govern functioning and stability of biofilms [3]. Moreover, they also contribute to enhance functioning of ecosystems like soil and human body [7].

In the FBB, number of high molecular weight metabolites (HMWMs) was significantly higher than that of low molecular weight metabolites (LMWMs) $(\mathrm{P}<$ 0.05, Figure 5). In natural systems, the HMWMs like multifunctional enzymes

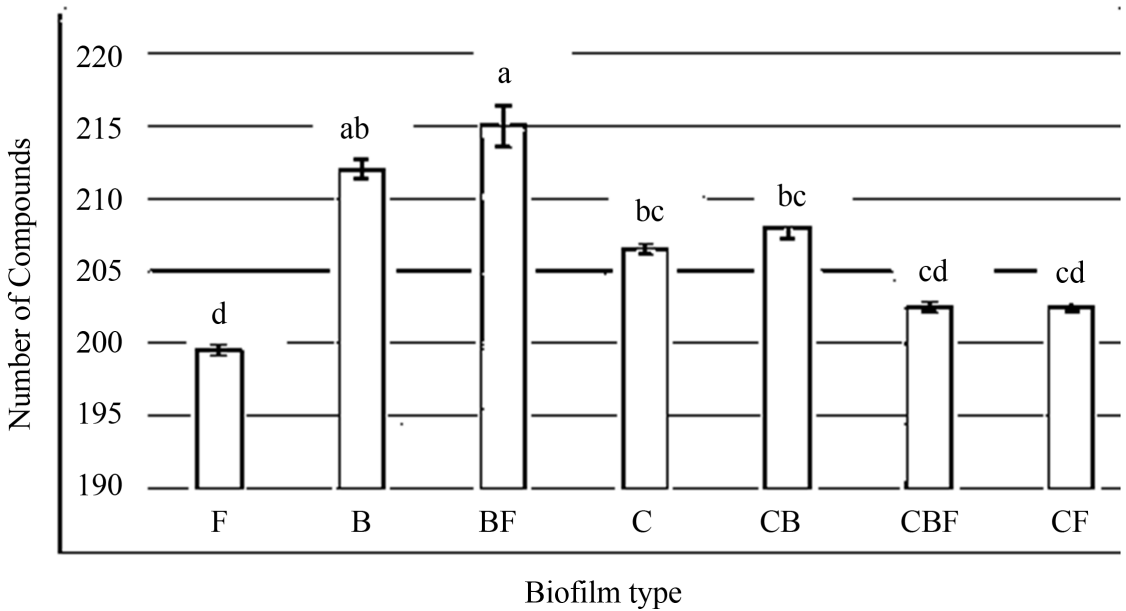

Figure 3. Total number of compounds of the EPS produced by different mono and mixed culture biofilms. B-bacterial, F-fungal, C-cyanobacterial, BF-bacterial-fungal, $\mathrm{CB}-$ cyanobacterial-bacterial, $\mathrm{CF}$-cyanobacterial-fungal, $\mathrm{CBF}$ - cyanobacterial-bacterial-fungal. 


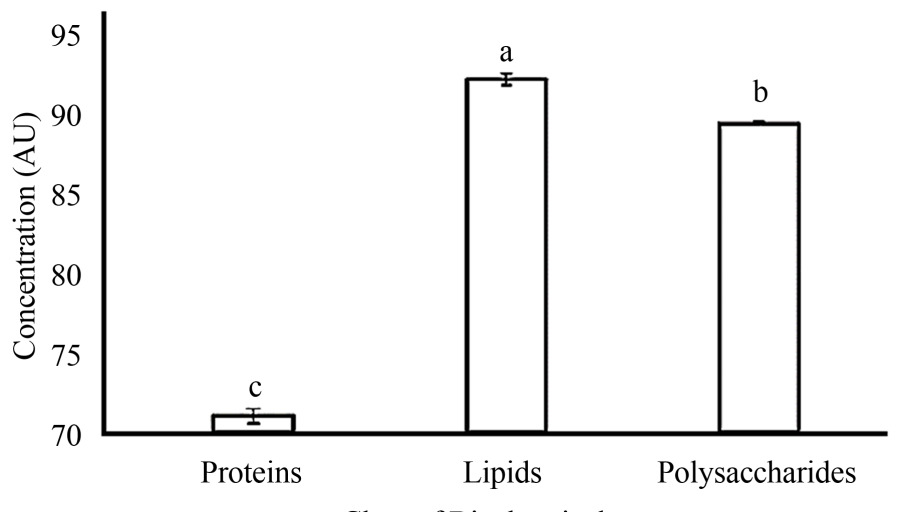

Class of Biochemicals

Figure 4. Biochemicals in the EPS of the developed Aspergillus niger-Stenotrophomonas maltophilia biofilm.

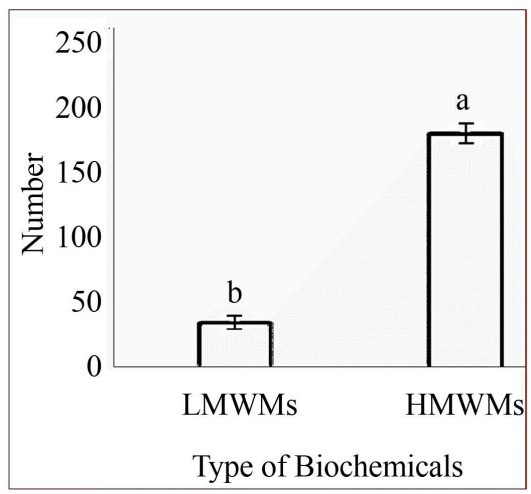

Figure 5. Number of biochemicals in the EPS of the developed Aspergillus niger-Stenotrophomonas maltophilia biofilm characterized by its molecular weight. Low molecular weight metabolites (LMWMs, $<900 \mathrm{kDa}$ ), High molecular weight metabolites (HMWMs, $>900$ $\mathrm{kDa})$.

work for the generation of diverse chemistry. The LMWMs participate in globally important processes which determine the physiological characteristics of Prokaryotes, Archaea and Eukaryotes, and also regulation of species-species relations [19]. Those processes influence biomineralization and even the ozone level in the stratosphere [20].

\section{Identification of Biochemicals in Biofilm-EPS}

In the A. niger-S. maltophilia biofilm, 214 biochemicals were detected from LCMS, and only 5 of them were fully identified. In addition, 14 biochemicals were predicted with $90.3 \%$ - $98.9 \%$ probability. In all, only $9 \%$ of the biochemicals of the LC-MS spectrum was characterized.

Most of the biochemicals identified belong to compounds related to medicines, and the rest to agrochemicals, bioremediating agents and industrially important chemicals which are used individually in our society (Table 1 and Table 2 ). However, they collectively carry out many physicochemical and biological functions via nodes of the complex interactive biochemical networks in the natural environment. For example, plant growth promoting rhizobacteria (PGPR) 
Table 1. Biochemicals identified from the Aspergillus niger-Stenotrophomonas maltophilia biofilm-EPS.

\begin{tabular}{|c|c|c|}
\hline Biochemical molecule & Structure & Action/Use \\
\hline Cholest-5-en-3-one & & $\begin{array}{l}\text { Steroid drug that has } \\
\text { positive uses against } \\
\text { obesity, liver disease, } \\
\text { and keratinization [21] }\end{array}$ \\
\hline Ergosterol & & $\begin{array}{l}\text { The precursor of } \\
\text { vitamin } \mathrm{D}_{2}[22]\end{array}$ \\
\hline Kepone & & $\begin{array}{l}\text { Used as an insecticide } \\
\text { [23] }\end{array}$ \\
\hline Syrosingopine & & $\begin{array}{l}\text { An antihypertensive } \\
\text { agent related to } \\
\text { reserpine that was found } \\
\text { to potentiate the } \\
\text { anticancer effects of the } \\
\text { antidiabetic agent } \\
\text { metformin and } \\
\text { phenformin } \\
\text { unaccompanied by } \\
\text { harmful effects on } \\
\text { normal cells [24] }\end{array}$ \\
\hline$\beta$ Carotene & & $\begin{array}{l}\text { The precursor of } \\
\text { vitamin A [25] }\end{array}$ \\
\hline
\end{tabular}

Table 2. Predicted biochemicals in the Aspergillus niger-Stenotrophomonas maltophilia biofilm-EPS

\begin{tabular}{ccc}
\hline Biomolecule & Action/Use & $\begin{array}{c}\text { Probability } \\
\text { (\%) }\end{array}$ \\
\hline $\begin{array}{c}\text { 1,2-Benzenedicarboxylic acid, } \\
\text { dinonyl ester }\end{array}$ & $\begin{array}{c}\text { Prevention of oxidative stress-induced } \\
\text { neurodegenerative disorders [26] }\end{array}$ & 93.0 \\
9,10-Anthracenedione, 2-ethyl- & Anticancer compound [27] & 96.4 \\
Bufotalin & Anticancer compound [28] [29] & 90.3 \\
\hline
\end{tabular}




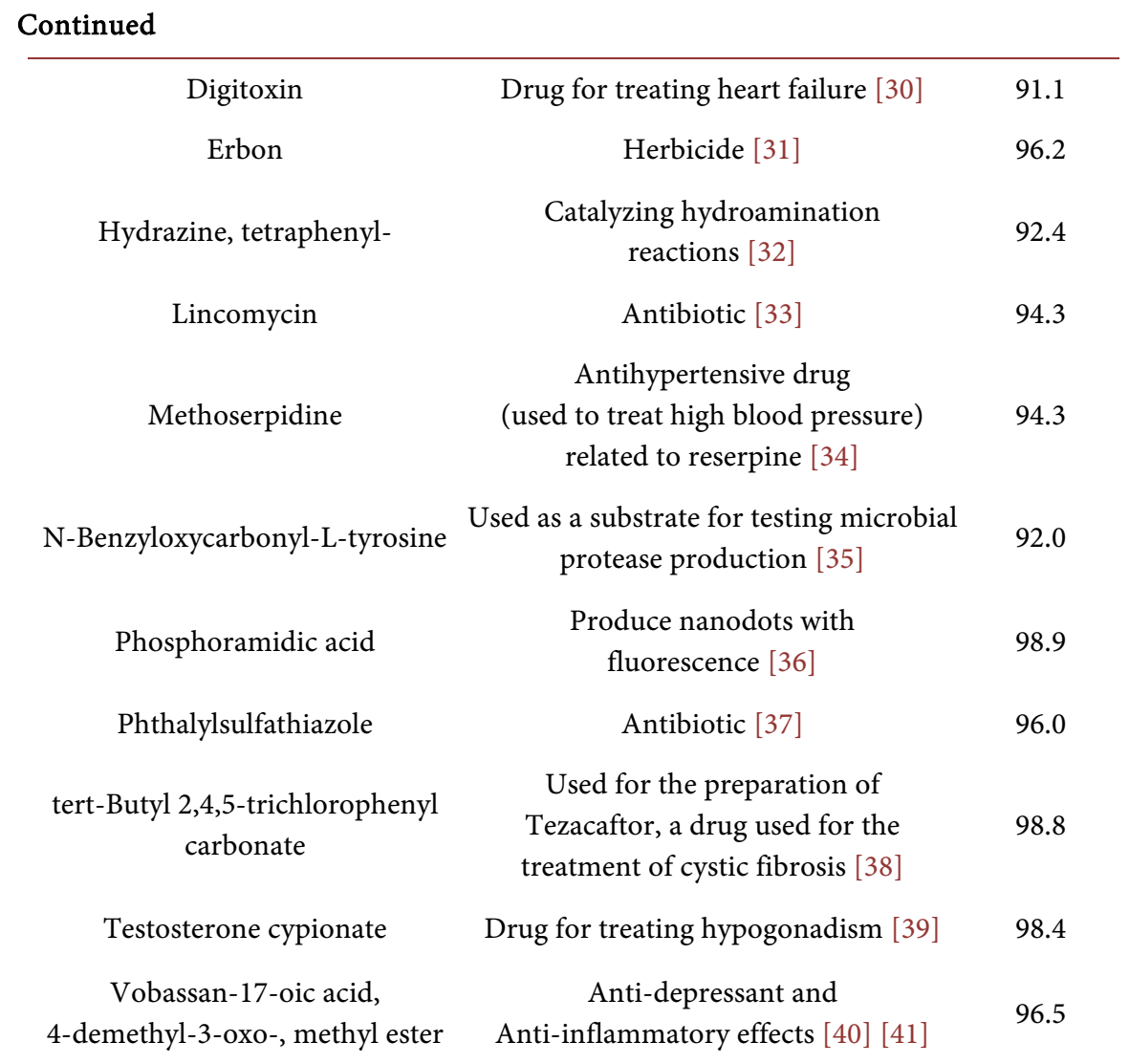

exert their action in the rhizosphere by producing a wide array of extracellular molecules for communication and defense, which play a crucial role in biochemical networks for beneficial plant-microbe interactions [42]. A similar functioning has been observed in metabolic networks of human gut microbiome [43].

Microbial society of a complex biofilm is comparable to human society. The biofilm microbes produce the biochemicals (goods) they require for their functioning and health, which lead to sustenance. The biochemicals used by the biofilms are as same as those which are utilized by the human society. The striking difference is that humans use them individually with some adverse side effects and relatively low efficacy whereas the biofilm microbes utilize them simultaneously to improve the network interactions, which leads to better functioning in the environment, as has already been exemplified in agriculture [6]. This striking difference in utilization of the biochemicals and their enhanced effect when they act simultaneously needs further investigations. Moreover, some behavioral patterns and intelligence of microbes are analogous to those of humans [44] [45]. These similar features clearly show the historical evolution of life starting from microbes on the earth.

At present, the ecologically important biochemicals are depleted in the nature due to degradation caused by anthropogenic activities, and it leads to deteriorate ecosystem health [46]. When biochemicals are added to any degraded ecosystem, 


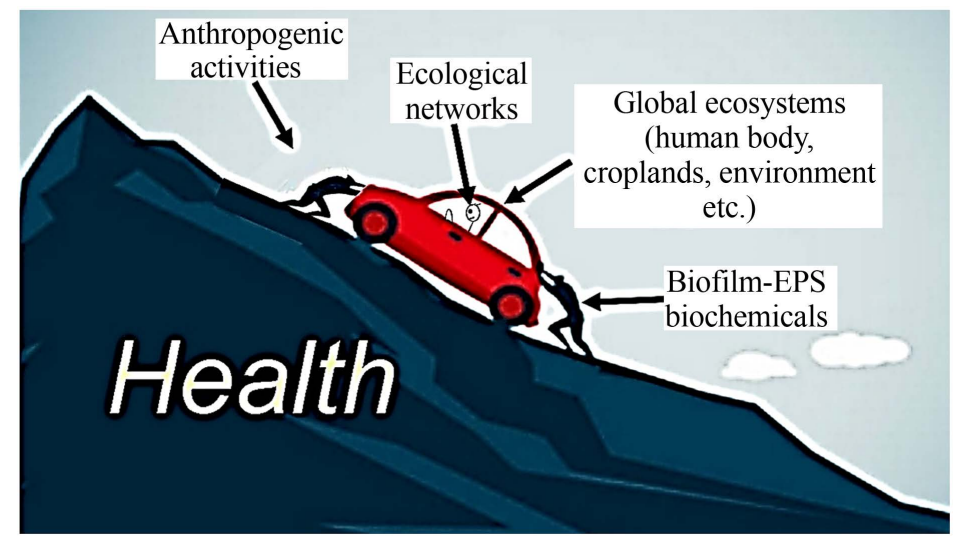

Figure 6. A cartoon showing the action of biofilm-EPS biochemicals in reinstating the health of global ecosystems.

its biodiversity will increase with simultaneous improvement of ecosystem functioning that leads to reinstate ecosystem health. The biofilm-EPS is a good candidate in supplying the biochemicals to any degraded ecosystem for its recovery, as depicted in the cartoon in Figure 6. This concept is valid for managed as well as natural ecosystems, including even human body ecosystem [7] [46].

\section{Conclusion}

The diverse biofilms used in the present study showed distinct morphological characteristics during their formation. Among them, fungal-bacterial-cyanobacterial biofilms and fungal-bacterial biofilms are in the forefront when considering the quantity of EPS produced and their biochemical diversity, respectively. Moreover, numerous important biochemicals are generated in the biofilm-EPS suggesting a huge potential of reinstating degraded ecosystems, including human body ecosystem. However, the current practice of utilizing the biochemicals by the human society needs revisiting, if we are to reduce their adverse side effects and also to further improve their efficacy of action in various applications.

\section{Acknowledgements}

All the members of Microbial Biotechnology Unit of the NIFS are acknowledged for their support during this study. We would also like to show our gratitude to all who collaborated by providing insights and expertise that greatly assisted the research.

\section{Conflicts of Interest}

The authors declare no conflicts of interest regarding the publication of this paper.

\section{References}

[1] Favre, L., Ortalo-Magné, A., Pichereaux, C., Gargaros, A., Burlet-Schiltz, O., Cotelle, V. and Culioli, G. (2018) Metabolome and Proteome Changes between Biofilm and 
Planktonic Phenotypes of the Marine Bacterium Pseudoalteromonas lipolytica TC8. Biofouling, 34, 132-148. https://doi.org/10.1080/08927014.2017.1413551

[2] Resch, A., Rosenstein, R., Nerz, C. and Götz, F. (2005) Differential Gene Expression Profiling of Staphylococcus aureus Cultivated under Biofilm and Planktonic Conditions. Applied and Environmental Microbiology, 71, 2663-2676.

[3] Flemming, H.C. and Wingender, J. (2010) The Biofilm Matrix. Nature Reviews Microbiology, 8, 623-633. https://doi.org/10.1038/nrmicro2415

[4] Seviour, T., Derlon, N., Dueholm, M.S., Flemming, H.C., Girbal-Neuhauser, E., Horn, H., Kjelleberg, S., van Loosdrecht, M.C., Lotti, T., Malpei, M.F. and Nerenberg, R. (2019) Extracellular Polymeric Substances of Biofilms: Suffering from an Identity Crisis. Water Research, 151, 1-7. https://doi.org/10.1016/j.watres.2018.11.020

[5] Seneviratne, G., Kecskés, M.L. and Kennedy, I.R. (2008) Biofilmed Biofertilisers: Novel Inoculants for Efficient Nutrient Use in Plants. In: Kennedy, I.R., Choudhury, A.T.M.A., Kecskés, M.L. and Rose, M.T., Eds., Efficient Nutrient Use in Rice Production in Vietnam Achieved Using Inoculant Biofertilisers, Australian Centre for International Agricultural Research, Canberra, 126-130.

http://biogro.com.vn/wp-content/uploads/ACIAR-PR130-onlineKennedyetal-BioG ro-Research.pdf\#page $=127$

[6] Premarathna, M., Seneviratne, G., Ketipearachchi, K.G., Pathirana, A., Karunaratne, R.K.C., Balasooriya, W.K. and Fonseka, K. (2021) Biofilm Biofertilizer Can Reinstate Network Interactions for Improved Rice Production. Ceylon Journal of Science, 50, 235-242.

[7] Seneviratne, G. and Premarathna, M. (2020) Biofilm Medicines: Next-Generation Drugs. https://doi.org/10.13140/RG.2.2.24088.14081

[8] Di Martino, P. (2018) Extracellular Polymeric Substances, a Key Element in Understanding Biofilm Phenotype. AIMS Microbiology, 4, 274-288. https://doi.org/10.3934/microbiol.2018.2.274

[9] Higa, T. and Wididana, G.N. (1991) The Concept and Theories of Effective Microorganisms. Proceedings of the First International Conference on Kyusei Nature Farming, Khon Kaen, 17-21 October 1989, 118-124.

[10] Seneviratne, G. (2003) Development of Eco-Friendly, Beneficial Microbial Biofilms. Current Science, 85, 1395-1396.

[11] Brenner, K., You, L. and Arnold, F.H. (2008) Engineering Microbial Consortia: A New Frontier in Synthetic Biology. Trends in Biotechnology, 26, 483-489. https://doi.org/10.1016/j.tibtech.2008.05.004

[12] Rosche, B., Li, X.Z., Hauer, B., Schmid, A. and Buehler, K. (2009) Microbial Biofilms: A Concept for Industrial Catalysis? Trends in Biotechnology, 27, 636-643. https://doi.org/10.1016/j.tibtech.2009.08.001

[13] Rennie, R.J. (1981) A Single Medium for the Isolation of Acetylene-Reducing (Dinitrogen-Fixing) Bacteria from Soils. Canadian Journal of Microbiology, 27, 8-14. https://doi.org/10.1139/m81-002

[14] Dorina, S., Judith, S., Björn, W., Julia, S., Andrea, S., Muffler, K. and Roland, U. (2020) A New Strategy for a Combined Isolation of EPS and Pigments from Cyanobacteria. Journal of Applied Phycology, 32, 1729-1740.

https://doi.org/10.1007/s10811-020-02063-x

[15] Ferro, L., Gojkovic, Z., Gorzsás, A. and Funk, C. (2019) Statistical Methods for Rapid Quantification of Proteins, Lipids, and Carbohydrates in Nordic Microalgal Species Using ATR-FTIR Spectroscopy. Molecules, 24, Article No. 3237. 
https://doi.org/10.3390/molecules24183237

[16] Bandara, W.M.M.S., Seneviratne, G. and Kulasooriya, S.A. (2006) Interactions among Endophytic Bacteria and Fungi: Effects and Potentials. Journal of Bioscience, 31, 645650. https://doi.org/10.1007/bf02708417

[17] Herath, H.M.L.I., Senanayeke, D.M.N., Seneviratne, G. and Bandara, D.C. (2013) Variation of Biochemical Expressions of Developed Fungal-Bacterial Biofilms over Their Monocultures and Its Effect on Plant Growth. Tropical Agricultural Research, 24, 186-192.

[18] Seneviratne, G. (2019) Microbial Biofilm Engineering: A Next-Generation Biotechnological Application (Keynote Speech). The International Conference on Biotechnology and Food Science (IAECST 2019), Guangzhou, 20-22 December 2019.

[19] Davies, J. (2013) Specialized Microbial Metabolites: Functions and Origins. The Journal of Antibiotics, 66, 361-364. https://doi.org/10.1038/ja.2013.61

[20] Stonik, V. and Stonik, I. (2015) Low-Molecular-Weight Metabolites from Diatoms: Structures, Biological Roles and Biosynthesis. Marine Drugs, 13, 3672-3709. https://doi.org/10.3390/md13063672

[21] Wu, K., Li, W., Song, J. and Li, T. (2015) Production, Purification, and Identification of Cholest-4-en-3-One Produced by Cholesterol Oxidase from Rhodococcus sp. in Aqueous/Organic Biphasic System. Biochemistry Insights, 8S1, BCI-S21580. https://doi.org/10.4137/BCI.S21580

[22] Papoutsis, K., Grasso, S., Menon, A., Brunton, N.P., Lyng, J.G., Jacquier, J.C. and Bhuyan, D.J. (2020) Recovery of Ergosterol and Vitamin $\mathrm{D}_{2}$ from Mushroom WastePotential Valorization by Food and Pharmaceutical Industries. Trends in Food Science \& Technology, 99, 351-366. https://doi.org/10.1016/j.tifs.2020.03.005

[23] Hammond, B., Katzenellenbogen, B.S., Krauthammer, N. and McConnell, J. (1979) Estrogenic Activity of the Insecticide Chlordecone (Kepone) and Interaction with Uterine Estrogen Receptors. Proceedings of the National Academy of Sciences of the United States of America, 76, 6641-6645.

[24] Kalam, M.A., Alkholief, M., Badran, M., Alshememry, A. and Alshamsan, A. (2020) Co-Encapsulation of Metformin Hydrochloride and Reserpine into Flexible Liposomes: Characterization and Comparison of in Vitro Release Profile. Journal of Drug Delivery Science and Technology, 57, Article ID: 101670. https://doi.org/10.1016/j.jddst.2020.101670

[25] Johra, F.T., Bepari, A.K., Bristy, A.T. and Reza, H.M. (2020) A Mechanistic Review of $\beta$-Carotene, Lutein, and Zeaxanthin in Eye Health and Disease. Antioxidants, 9 , Article No. 1046. https://doi.org/10.3390/antiox9111046

[26] Choi, S.J., Kim, M.J., Heo, H.J., Kim, J.K., Jun, W.J., Kim, H.K., Kim, E.K., Kim, M.O., Cho, H.Y., Hwang, H.J., Kim, Y.J. and Shin, D.H. (2009) Ameliorative Effect of 1,2-Benzenedicarboxylic Acid Dinonyl Ester against Amyloid Beta Peptide-Induced Neurotoxicity. Amyloid, 16, 15-24. https://doi.org/10.1080/13506120802676997

[27] Chou, K.M., Krapcho, A.P., Horn, D. and Hacker, M. (2002) Characterization of Anthracenediones and Their Photoaffinity Analogs. Biochemical Pharmacology, 63, 1143-1147. https://doi.org/10.1016/S0006-2952(02)00855-9

[28] Chao, X., Zhou, X.J., Dong, C.H. and Zheng, G. (2014) The Effect and Mechanism of Apoptosis on Hela Cells Induced by Bufotalin. Advanced Materials Research, 834-836, 568-572. https://doi.org/10.4028/www.scientific.net/AMR.834-836.568

[29] You, C.L. and Hou, H.M. (2011) Plasma Pharmacokinetics and Tissue Distribution of Bufotalin in Mice Following Single-Bolus Injection and Constant-Rate Infusion of Bufotalin Solution. European Journal of Drug Metabolism and Pharmacokinetics, 
35, 115-121. https://doi.org/10.1007/s13318-010-0017-6

[30] Arispe, N., Diaz, J.C., Simakova, O. and Pollard, H.B. (2008) Heart Failure Drug Digitoxin Induces Calcium Uptake into Cells by Forming Transmembrane Calcium Channels. Proceedings of the National Academy of Sciences of the United States of America, 105, 2610-2615.

[31] Bleicher, D.P., Scorup, P.C. and Mitchell, W.W. (1980) Pesticide Use in Alaska, 1978. Agricultural Experiment Station, University of Alaska, Fairbanks.

[32] Couce-Rios, A., Kovacs, G., Ujaque, G. and Lledos, A. (2015) Hydroamination of C-C Multiple Bonds with Hydrazine Catalyzed by N-Heterocyclic Carbene-Gold(I) Complexes: Substrate and Ligand Effects. ACS Catalysis, 5, 815-829. https://doi.org/10.1021/cs501705b

[33] Spížek, J. and Řezanka, T. (2004) Lincomycin, Clindamycin and Their Applications. Applied Microbiology and Biotechnology, 64, 455-464. https://doi.org/10.1007/s00253-003-1545-7

[34] Jones, D.L., Michael, A.M. and Ommer, J.P. (1961) Clinical Trial of Methoserpidine in General Practice. British Medical Journal, 2, 1738-1741.

[35] Hageman, J.H. and Carlton, B.C. (1973) Effects of Mutational Loss of Specific Intracellular Proteases on the Sporulation of Bacillus subtilis. Journal of Bacteriology, 114, 612-617.

[36] Zhao, L., Liu, Z.F., Jin, W.J. and Feng, F. (2021) Luminescence Property of Phosphoramidic Acid Oligomer Nanodots in Aqueous Solution. Spectrochimica Acta Part A: Molecular and Biomolecular Spectroscopy, 248, Article ID: 119261. https://doi.org/10.1016/j.saa.2020.119261.

[37] Taylor, D.N., Hamer, D.H. and Shlim, D.R. (2017. Medications for the Prevention and Treatment of Travellers' Diarrhea. Journal of Travel Medicine, 24, S17-S22. https://doi.org/10.1093/jtm/taw097

[38] Emmett, M.R., Bodhuri, P., Zhao, Y., Cammisa, E.G. and Green, S.P. (2020) U.S. Patent No. 10875846B2. U.S. Patent and Trademark Office, Washington DC. https://patents.google.com/patent/US10875846B2/en

[39] Rey, R.A. and Grinspon, R.P. (2020) Androgen Treatment in Adolescent Males with Hypogonadism. American Journal of Men's Health, 14, Article ID: 1557988320922443. https://doi.org/10.1177/1557988320922443

[40] Surana, A.R. and Wagh, R.D. (2017) GC-MS Profiling and Antidepressant-Like Effect of the Extracts of Hamelia Patens in Animal Model. Bangladesh Journal of Pharmacology, 12, 410-416.

[41] Fesenko, A.A. and Shutalev, A.D. (2018) A General Stereo Selective Approach to 1,2,4-Triazepane-3-Thiones/Ones via Reduction or Reductive Alkylation of 2,4,5,6Tetrahydro-3H-1,2,4-Triazepine-3-Thiones/Ones. Multidisciplinary Digital Publishing Institute Proceedings, 9, Article No. 14.

[42] Rosier, A., Medeiros, F.H. and Bais, H.P. (2018) Defining Plant Growth Promoting Rhizobacteria Molecular and Biochemical Networks in Beneficial Plant-Microbe Interactions. Plant and Soil, 428, 35-55. https://doi.org/10.1007/s11104-018-3679-5

[43] Magnúsdóttir, S. and Thiele, I. (2018) Modeling Metabolism of the Human Gut Microbiome. Current Opinion in Biotechnology, 51, 90-96. https://doi.org/10.1016/j.copbio.2017.12.005

[44] Gryndler, M., Gryndlerová, H., Hujslová, M., Bystrianský, L., Malinská, H., Šimsa, D. and Hršelová, H. (2021) In Vitro Evaluation of Biofilm Biomass Dynamics. Microbiology, 90, 656-665. https://doi.org/10.1134/S0026261721050064

[45] Westerhoff, H.V., Brooks, A.N., Simeonidis, E., García-Contreras, R., He, F., Boogerd, 
F.C., Jackson, V.J., Goncharuk, V. and Kolodkin, A. (2014) Macromolecular Networks and Intelligence in Microorganisms. Frontiers in Microbiology, 5, Article No. 379. https://doi.org/10.3389/fmicb.2014.00379

[46] Seneviratne, G., Premarathna, M. and Jayasekara, A. (2020) Ecologically Important, a Wider Range of Biochemical Molecules Secreted by Microbial Biofilms Can Give Life and Reinstate Lost Ecosystem Sustainability. National Institute of Fundamental Studies, Kandy. https://doi.org/10.13140/RG.2.2.27873.94565 